\title{
The Factors Affecting Teachers' Readiness In Developing Science Concept Assessment Through Inquiry-Based Learning Process In Elementary Schools
}

\author{
A. Ketut Budiastra \\ Universitas Terbuka, Indonesia \\ Nia Erlina \\ Institut Agama Islam Negeri Jember, Indonesia \\ Iwan Wicaksono \\ University of Jember, Indonesia
}

\begin{abstract}
Teachers need to develop their professionalism in teaching to achieve $21^{\text {st }}$ century learning competencies. The role of the teacher is not only to provide information but also to assess the learning process and outcomes comprehensively and in an integrated manner. This study aimed to describe the factors that support the readiness of teachers to carry out assessments in inquiry-based science in elementary schools. Respondents in this study were 87 elementary school teachers who were 87 students spread across four regions of the UT Regional Office namely Pangkalpinang, Jakarta, Denpasar, and Kupang. These four regions of the UT Regional Office were chosen as a representation of the regions of West, Central and East Indonesia. From this sample, teachers were examined to see their readiness to compose a lesson plan and carry out an inquiry assessment. Next, teachers filled in the response sheet to find out their readiness to carry out an inquiry assessment in science learning in elementary schools. Teaching inquiry-based science required teachers to spend more time preparing lesson plans to prepare tools and learning materials. Factors which supported the readiness of teachers to measure the inquiry-based science learning process in elementary schools, including their sufficient capacity to develop lesson plans which were oriented to the inquiry process, peer support and teachers' working group. Some efforts were done to overcome obstacles namely developing the ability to assess the mastery of science concepts through inquiry-based learning processes in elementary schools, utilizing teachers' working group (TWG) and the support of school principals/assessors to make relevant assessment tools.
\end{abstract}

Key words: assessment, science, inquiry, elementary school teachers

\section{INTRODUCTION}

Assessment is a structured activity of a teacher which is carried out comprehensively and integrated with the learning process. Curriculum 2013 in elementary school has set the planning, implementation and processing of assessments by teachers. Assessment techniques used by teachers in elementary schools are assessment through attitudes, knowledge, and skills (Demir, Tananis, \& Trahan, 2019). Attitude assessment is intended as an assessment of student behavior in the learning process which includes spiritual and social attitudes (Şimşir, Seki, \& Dilmaç, 2018). Affective assessment is intended to foster behavior in the context of shaping student character. Knowledge assessment is carried out by measuring student mastery which includes dimensions of factual, conceptual, procedural and metacognitive knowledge at various levels of the thought process. Knowledge assessment procedures start from the 
preparation of planning, development of assessment instruments, implementation of assessment, processing, and reporting, as well as utilization of assessment results (Popescu, 2019). Skill assessment is carried out by the assessment of performance, project, and portfolio. In performance, the emphasis can be placed on the process or product. Project is an activity of evaluating a task that must be completed within a certain period/ time. Portfolio is collection of documents resulting from assessments, awards, and student work in certain field that reflect development (reflective-integrative) over a certain period of time (Sherfinski, Jalalifard, Zhang, \& Hayes, 2019).

The learning process of science subject in elementary school requires teachers to be able to provide and managing science learning with approaches and supporting techniques that enable students to experience all stages of learning which contain process skills, scientific attitude, and mastery of concepts. The inquiry approach is an approach that prepares students in an atmosphere to conduct their own extensive experiments so that they can see what is happening, want to do something, ask questions and find answers themselves (GarcíaCarmona, 2019). Inquiry involves students to connect one finding with another and compare what is found by other students. Some findings indicate weaknesses of inquiry-based learning including: (1) Inquiry is used as a learning model, so it will be difficult to control student activities and success; (2) This model is difficult in planning the learning process, because it contrasts with students' learning habits; (3) Implementation of inquiry requires a long time so it is often difficult for teachers to adjust it to the allotted time; (4) All success criteria are determined by students' ability to master the subject matter, so the inquiry model will be difficult to be implemented by every teacher (Cairns \& Areepattamannil, 2019). Teacher professionalism competence is more focused on teachers to master the learning material widely and deeply. Although the curriculum training has been carried out, there are still many teachers who admit that it is difficult, complicated and confusing to master this new curriculum, especially how to assess students (Arnold, Boone, Kremer, \& Mayer, 2018). Many different opinions about how to assess make the teachers confuse to apply it in the field. The teachers feel that the demands of assessment on the curriculum make teachers difficult. As a result, each school has differences in assessing the students (Hondrich, Hertel, Adl-Amini, \& Klieme, 2016).

However, from previous studies found that the test models developed in science tend to only focus on the aspects of knowledge, especially facts (M. M. Arnold, Graham, \& HollingworthHughes, 2017). In addition, the types of questions developed do not support the learning of science using the inquiry approach in the classroom. Supposedly, questions asked in daily tests, midterms, final terms, or national examinations should not only ask aspects of knowledge by revealing facts or concepts but should also ask questions regarding aspects of why and how (Budiastra \& Purwoningsih, 2014). In other words, questions asked to students should also include questions that require students to be able to answer questions that demand a higher level of ability such as analytical and synthesis questions adjusted to development level of children around elementary school age (Handayani, Hartono, \& Sustainable, 2019). From the results of the study, it can be suggested that questions that should be tested at the school level, or national final examination also contain questions based on inquiry, so that teachers feel how important it is to introduce elementary school children to carry out inquiry-based science learning. The dimension of developing aspects of knowledge, skills and attitudes introduced through science should be well understood by teachers so that they feel they have a moral obligation to introduce the approach to students through various topics or subtopics of science taught in elementary schools. 


\section{PERSPECTIVE}

\section{Assessment}

The teachers' assessment is aimed at determining the level of students' learning outcomes as well as feedback for improving the learning process by using relevant instruments (Boud \& Soler, 2016). The level of students' learning achievement is in the form of a level of student mastery of the material that has been given, skills, motivation, talents, interests, attitudes of students towards the learning program, the level of progress and suitability of student learning outcomes with the standard competencies and basic competencies that have been set (Uçar \& Sungur, 2017). Teachers must know what basic competence have been mastered by students and take immediate corrective actions when there are students with low grades or perform less than the expectations. Four important awareness points for teachers in giving an assessment are (1) Sense of goal, measuring the ability or competence of students after the learning process is done in accordance with indicators in standard of competence and basic competence which must be mastered by students; (2) Sense of regulation, making questions which are full of regularity and in accordance with the blueprints based on agreement between fellow teachers and school principals; (3) Sense of achievement, able to make every student be high-achiever and discover their unique potential; (4) Sense of harmony, academic and nonacademic abilities that are harmonious and balanced (Semken \& Freeman, 2008).

\section{Science}

Science is the study of conditions and events in nature systematically through observation and experiments to find out facts, concepts, processes of discovery and scientific attitudes (Fuller, 2019). Learning is a process of educating the students by systematic planning, implementation, and evaluation so that students can achieve learning objectives effectively and efficiently. Science learning process is carried out to teach students to understand the nature of science (processes, products and their applications) to develop an attitude of curiosity, determination, perseverance and awareness of the values that exist in society and the development of positive attitudes (Akerson, Carter, Pongsanon, \& Nargund-Joshi, 2019). The purpose of learning science in elementary schools is to help students to get ideas, understanding, experience, skills and abilities to think scientifically and be able to apply them in life properly and be responsible. Science for elementary schools is adjusted to the stages of cognitive development (Deieso \& Fraser, 2019). According to Piaget, each individual experiences the following levels of intellectual development: (1) Motor sensory (0-2 years); at this stage the child regulates his nature with his senses and actions (motor); (2) Pre operational (2-7 years), at this stage the child has not been able to carry out mental operations; (3) Concrete operations (7-11 years), at this stage the child begins to think rationally and is willing to accept the opinions of others; (4) Operational formal (11 years and over), at this stage children can formulate many alternative hypotheses in responding to problems and thinking as adults (Demetriou et al., 2018). From this theory, it is clear that elementary students are generally at a concrete operational stage.

\section{Inquiry-based Learning}

Inquiry is one of the strategies used in process-oriented classrooms; it is a student-centered teaching strategy that encourages students to investigate problems and find information (Chevalier \& Buckles, 2019). The learning process that uses inquiry model can be carried out by following the steps as follows: (1) Orientation, fostering a responsive learning atmosphere so that it can stimulate and encourage students to solve problems; (2) Formulating the problem, bringing students to a puzzling problem; (3) Propose a hypothesis, a temporary answer to a problem being studied which needs to be tested for truth as a temporary answer; (4) Collecting data, capturing information needed to test the proposed hypothesis including experiment or experiment; (5) Testing the hypothesis, determining the answers considered acceptable in accordance with the data or information obtained based on data collection; (6) 
Formulating conclusions describing the findings obtained based on the results of hypothesis testing (Inoue, Asada, Maeda, \& Nakamura, 2019). The goal of inquiry learning is to develop the ability to think systematically, logically, and critically, or develop intellectual abilities as part of mental processes (Fry, Klages, \& Venneman, 2018). Some main characteristics of inquiry learning strategies are: (1) Optimizing students' activities to search and find, which means that the inquiry strategy places students as subjects of learning; (2) Directing students' activities to seek and find their own answers to the questions, so that it is expected to foster their confidence (self-belief); (3) Aiming to develop the ability to think systematically, logically, critically, or develop intellectual abilities as part of mental processes (Laursen \& Rasmussen, 2019).

\section{Teacher}

Teacher plays a major role in the development of education, especially those which are held formally in schools. The teacher also largely determines student success, especially in relation to the teaching and learning process (Liu \& Hallinger, 2018a). Teacher is the most influential component in creating quality educational processes and outcomes. As professional educator, teacher is required to have teacher professional competency in any level of education. Other competencies are personality competence, pedagogical competence, and social competence (Sayko, 2018). Based on observations, low student learning outcome is due to several factors, namely: (1) The teacher is not using appropriate learning approach, so the material delivered by the teacher is not optimally absorbed by students; (2) Students' lack motivation to learn; (3) Science learning processes give more emphasis on students' ability to memorize theories without developing students' ability to solve problems; (4) Teacher also tends to make students as learning objects, so students cannot develop the ability to think critically, creatively, innovatively, and systematically (Liu \& Hallinger, 2018b). This shift of paradigm in assessment requires teachers to take full control of learning activities. Of the three areas assessed in this curriculum, each of attitude, skills and knowledge aspect have different ways of assessment which are not the same as the previous curriculum. The teacher needs to think quickly, about both how to assess of students' understanding and direct interactions towards effective learning (Tican \& Deniz, 2019). The teacher must pinpoint the strengths of students and advise how to develop them, explain weaknesses and how they overcome them, as well as provide students with opportunities to improve their work (Tan, Whipp, Gagné, \& Van Quaquebeke, 2019).

\section{Participants}

\section{METHOD}

The population of this study was all the elementary school teachers who are taking the course of Strengthening Professional Capabilities in Faculty of Teacher Training and Education, Universitas Terbuka. The respondents were spread in four regions of UT Regional Office in Pangkalpinang, Jakarta, Denpasar, and Kupang, with the proportion shows in the following Table 1.

Table 1.

Spread of Respondents Based on the Research Location

\begin{tabular}{|c|c|c|c|}
\hline NO & $\begin{array}{c}\text { LOCATION } \\
\text { (UT REGIONAL OFFICE) }\end{array}$ & $\begin{array}{c}\text { NUMBER OF } \\
\text { RESPONDENTS }\end{array}$ & $\begin{array}{c}\text { PERCENTAGE } \\
(\%)\end{array}$ \\
\hline 1 & Pangkalpinang & 27 & 31,03 \\
\hline 2 & Jakarta & 20 & 22,99 \\
\hline 3 & Denpasar & 20 & 22,99 \\
\hline 4 & Kupang & 20 & 22,99 \\
\hline & TOTAL & 87 & 100 \\
\hline
\end{tabular}




\section{Case materials and discussion questions}

This research was based on preliminary studies fact which showed that teachers had difficulty implementing assessment in inquiry-based learning in elementary schools (Budiastra \& Purwoningsih, 2014). The focus of this study was to analyze the factors that influenced the readiness of teachers to develop assessments to measure the mastery of science concept through the inquiry-based learning process in elementary schools. The formulations of the problem were (1) How is the teacher's understanding of inquiry-based learning?; (2) What are the factors that support the readiness of teachers to measure the inquiry-based science learning process in elementary schools?; (3) What are the factors that inhibit the readiness of teachers to measure the inquiry-based science learning process in elementary schools?; (4) What are the efforts made by teachers to be able to develop assessment tools to measure the mastery of science concepts through inquiry-based learning processes in elementary schools?; and (5) What is the role of school principals/ supervisors/ assessors/ peers to support the readiness of teachers to develop assessment tools to measure the mastery of science concepts through inquiry-based learning processes in elementary schools?

\section{Instruments}

This study used a Likert Scale to measure and collect data by measuring and weighing the items of questions containing leveled choices (White et al., 2019). Data from respondents were collected using descriptive questionnaires which had levels. The responses of the elementary school teachers towards the questions in questionnaire were divided into five categories namely: $5=$ very satisfied (VS); $4=$ satisfied (S); 3= quite satisfied (QS); 2 = less satisfied (LS); 1 = very unsatisfied (VUS). Teachers from each UT Regional Office were studied tin terms of their readiness to plan inquiry assessments and carry out inquiry assessments in science subject in elementary schools. The ability to develop these questions would appear in the formative tests which they compiled in lesson plan for the task in Strengthening Professional Capabilities course. Then the teachers from each UT Regional Office were given in-depth interviewed to find out their readiness to carry out an inquiry-based assessment of science subject in elementary school.

\section{Data Analysis}

This research was a survey research, where the data were analyzed quantitatively and qualitatively. Qualitative data were processed by through organizing data, sorting out data to make units that can be managed, then sorting, grouping, coding, and categorizing them to generate finding. While quantitative data were processed based on how to retrieve data using questionnaires and analysis of lesson plan documents developed by the teachers.

\section{RESULTS AND DISCUSSION}

The results of this study presented data on several things, which are teachers' understanding on the importance of inquiry learning, factors that support and inhibit teacher readiness to measure inquiry-based science learning processes, efforts made teachers to be able to develop assessment tools to measure the mastery of science concepts through inquiry-based learning, and the role of school principals, supervisors, assessors, peers to support the readiness of teachers develop assessment tools to measure the mastery of science concepts through inquiry-based learning processes in elementary schools. In this study, respondents' understanding of inquiry-based science learning in elementary schools, including the importance of understanding and implementing them in learning science in elementary schools, was obtained by asking a number of questions which include: (1) Science was an interesting subject to be taught in elementary school; (2) Teaching science in elementary schools was identical to activities to manipulate teaching aids or materials or often referred to as hands-on activities; (3) Teaching science in elementary schools was identical to training 
process skills to elementary students; (4) Science was a difficult subject to be taught in elementary school; (5) Science required students to be active in the learning process to find the concepts they were learning; (6) To teach inquiry-based science required teachers to take more time to prepare the lesson, tools and learning materials (science equipment); and (7) Inquiry-based science learning did not only train and develop students' abilities in cognitive aspects, but also their affective aspects/ attitudes and psychomotor aspects/ students' skills. Elementary school teacher responses to inquiry and the importance of inquiry in learning science in elementary schools can be seen in Figure 1.

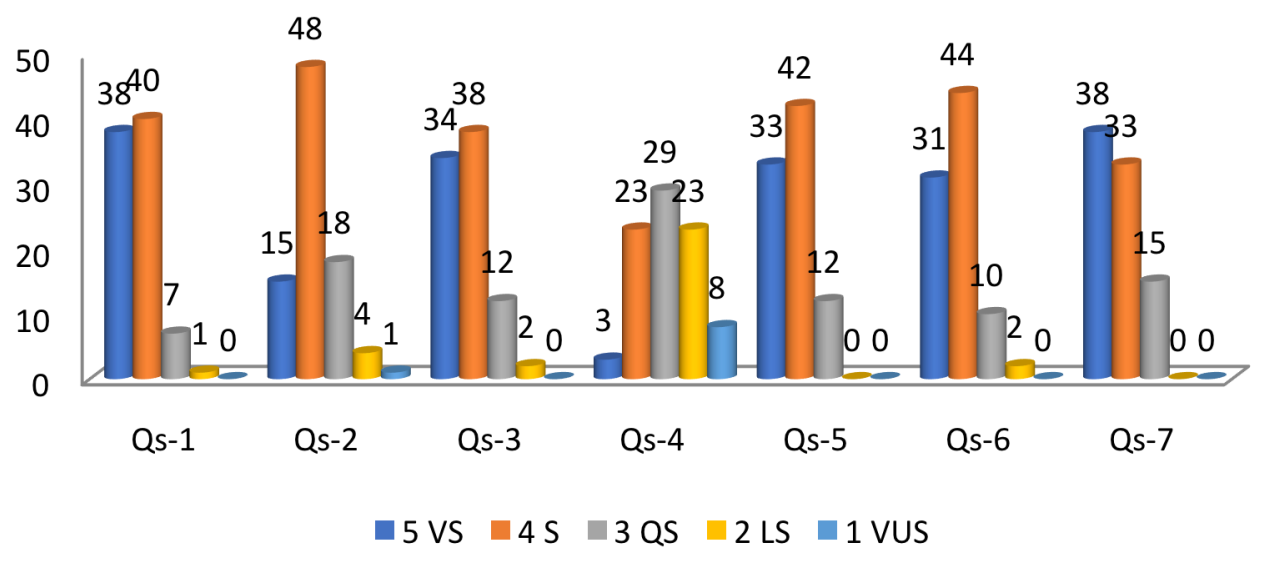

Figure 1.

Teachers' Responses toward the Importance of Inquiry-Based Science Learning in Elementary School

Figure 1 showed that science was an interesting subject matter, even it was very interesting to be taught in elementary school as stated by 78 respondents (89.66\%). In addition, 63 respondents $(72.41 \%)$ of elementary school teachers stated that teaching science in elementary school was identical to activities to manipulate teaching aids or materials or often referred to as hands-on activities, and as many as 72 respondents $(82.76 \%)$ stated that teaching science in elementary was identical to training process skills to elementary students. In terms of the level of difficulty in teaching science in elementary schools, 61 respondents $(70.11 \%)$ said that science was easy enough, easy and very easy to be taught in elementary school. However, there were 26 respondents (29.89\%) who stated that the material was quite difficult to teach in elementary school. In addition, 75 respondents (86.21) stated that the science required students to be active in the learning process to find the concepts they were learning. The other 75 respondents (86.21\%) said that to teach inquiry-based science required teachers to spend more time prepare the lesson, tools and learning equipment (science equipment). Almost all respondents agreed that learning science-based inquiry in elementary school in addition to training and developing students' abilities in cognitive aspects, also trained and developed aspects of affective/ attitude and psychomotor/ skills (Kuo, Tuan, \& Chin, 2019). Inquiry do not only train cognitive abilities but also trains affective and psychomotor abilities (Budiastra \& Purwoningsih, 2014).

The factors that supported the readiness of teachers to assess the inquiry-based science learning process in elementary schools were collected by asking questions/ statements which included: (1) Teachers had sufficient ability to develop lesson plans which were oriented to the inquiry process in science learning in elementary school; (2) In your opinion, peers from the same elementary school were very important so that you can assess the inquiry-based learning process in elementary school; (3) The work environment in elementary school played an important role so that you could assess the inquiry-based learning process in elementary 
school; (4) By the experience, the TWG was considered to have an important role in supporting your ability to be able to measure the inquiry-based science learning process in elementary school; and (5) Attending scientific activities (e.g. seminars, conferences, writing book, etc.) greatly helped you to develop the ability to be able to assess the learning process of inquirybased science in elementary school. The response of elementary school teachers to the factors that supported the readiness of teachers to measure the inquiry-based science learning process in elementary schools can be seen in Figure 2.

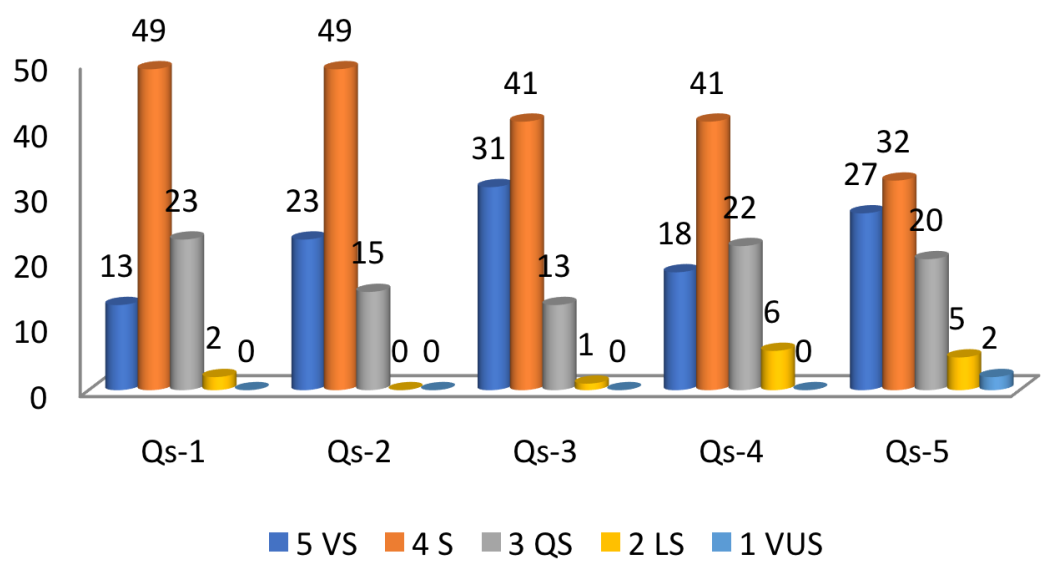

Figure 2.

Teachers' Responses toward the Factors which Support the Readiness to Measure the Process of Inquiry-Based Science Learning in Elementary School

The factors which supported the readiness of teachers to measure the inquiry-based science learning process in elementary schools among others were that they had sufficient ability to develop lesson plans (RPP) which were inquiry-oriented process in science learning in elementary schools (Owiny, Hollingshead, Barrio, \& Stoneman, 2019). In addition, peers from either the same elementary school or other elementary schools in the TWG had an important role, so that they could measure the learning process based on inquiry in elementary school. The working environment at the elementary school was also stated to play an important role so that they could measure the inquiry-based learning process in elementary school. TWG is considered to have quite an important role to support the ability of elementary school teachers to be able to measure the inquiry-based science learning process in elementary schools, although the role of TWG has not been optimum yet (Akiba, Murata, Howard, \& Wilkinson, 2019). Attending scientific activities (e.g. seminars, conferences, writing books and other forums) is stated to be sufficiently important for elementary school teachers to assist them in developing the ability to be able to measure the inquiry-based learning process of science in elementary schools (Öberg \& Campbell, 2019).

The factors that inhibit the readiness of teachers to measure the inquiry-based science learning process in elementary schools were collected by asking questions/ statements which included: (1) Lack of understanding to the importance of the ability to measure the mastery of student concepts based on inquiry-based science learning processes; (2) The number of materials or science concepts that students must master in one semester or in one year, so that the time to carry out the learning process based on inquiry could not be carried out properly; (3) Limited teaching aids or facilities and infrastructure to support the science learning process was considered as an obstacle to deliver the inquiry-based learning process in elementary school; (4) Lack of adequate training to measure the mastery of inquiry science concepts in elementary schools; (5) There was a laziness or reluctance to develop questions based on the inquirybased learning process in elementary schools; and (6) More time, energy, and material support 
were needed if the teacher wanted to measure the ability of students based on the inquirybased science learning process in elementary school. The distribution of respondents' answers to these questions can be seen in Table 5. In general, elementary teachers' responses to factors that inhibit the readiness of teachers to measure inquiry-based science learning processes in elementary schools can be seen in Figure 3.

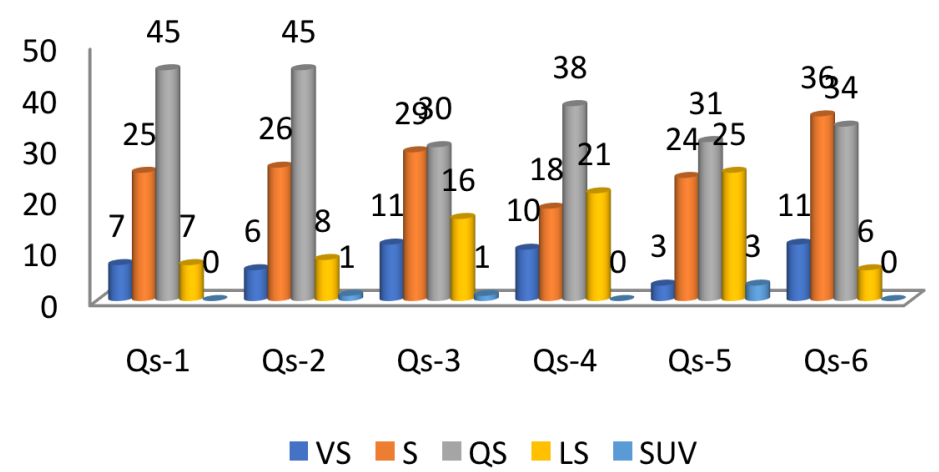

Figure 3.

\section{Teachers' Responses toward the Factors which Inhibit the Readiness to Measure} the Process of Inquiry-Based Science Learning in Elementary School

Laziness or reluctance to develop questions based on the inquiry-based learning process in elementary schools was categorized to be an obstacle in their readiness to measure inquiry-based learning processes in elementary schools. In addition, more time, energy, and material support are needed if the teachers want to measure the ability of students based on the inquiry-based science learning process in elementary schools (Le Hebel, Tiberghien, Montpied, \& Fontanieu, 2019). Similar obstacles are also found from the results of a study (Istianto, 2012) entitled "The Use of Inquiry Methods in Improving Mathematics Learning Outcomes in Class V of Elementary Schools" which stated that the obstacles that arise include: (1) the learning habits of some students who are still teacher-centered (conventional), (2) the time used in learning is not effective, (3) the learning resources of students are mostly bookoriented, and there are students who have a learning delay, so they have not been able to learn on their own in the activities which are carried out by inquiry-based learning. In line with the results of the previous study, the weaknesses of the inquiry method include: (1) adequate facilities needed, (2) the difficulty of changing conventional to active learning method, (3) the freedom given by teachers is sometimes not optimally utilized by students, so the learning process take longer time and ineffective (Vorholzer \& von Aufschnaiter, 2019).

The efforts made by teachers to develop assessment tools to measure the mastery of science concepts through the inquiry-based learning process in elementary schools were obtained by asking questions/ statements which include: (1) Using questions that were fully downloaded from the lesson plans available on the internet; (2) Adopting or making adjustments to the downloaded questions from the lesson plans available on the internet; (3) Developing questions by yourself to measure the mastery of science concept through the inquiry-based learning process in elementary schools; (4) Work plans and training plans in the TWG strongly supported you to carry out the inquiry-based learning process; (5) The TWG played a role in efforts to improve your ability to develop lesson plans or inquiry-based learning improvement plans in elementary schools; (6) TWG had a role in increasing your ability to apply ideas for implementing improved learning processes in the classroom; and (7) The TWG had a role in improving your ability to plan test instruments and apply them to your students. In general, elementary school teachers' responses to their efforts in developing assessment tools to 
measure the mastery of science concepts through inquiry-based learning processes in elementary schools can be seen in Figure 4.

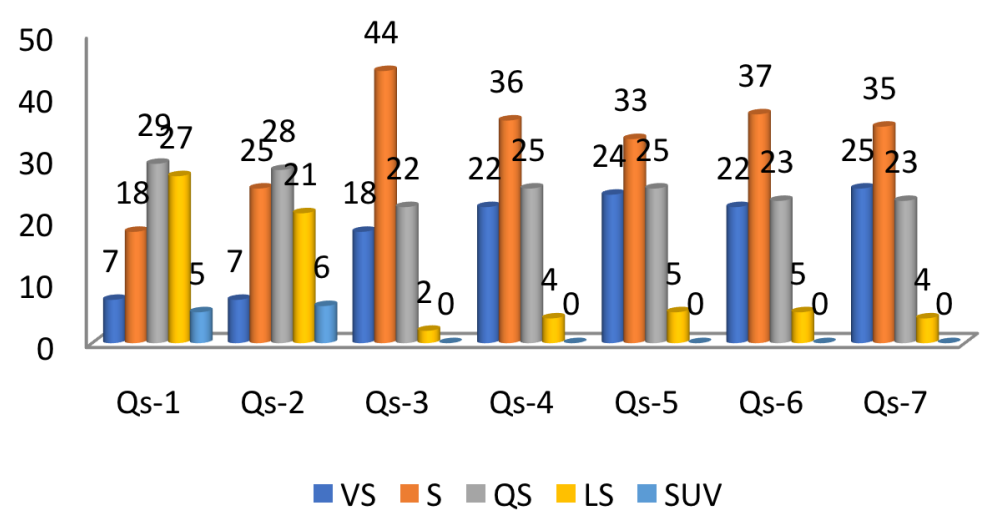

Figure 4.

Teachers' Efforts in Developing Assessment Tools to Measure the Mastery of Science Concepts Through Inquiry-Based Learning Processes in Elementary Schools

Figure 4 generally showed a satisfying response. Most teachers developed their own questions to measure the mastery of science concept through the inquiry-based learning process to carry out the inquiry-based learning process and to apply ideas to plan and implement improvements to the learning process in class. Some of the efforts which had been made to develop the ability of teachers to develop assessment tools were looking at assessment and teaching-learning activities in an integrated manner. The teacher can carry out various assessment strategies within the teaching program to provide various types of information about student learning outcomes (Lee, Baker, \& Haywood, 2018). The teachers need to consider various special needs of students. In compiling the assessment instruments the following items should be considered, among others (1) Material, for example the suitability of the questions with basic competencies and indicators of achievement at the curriculum of education unit level; (2) Construction, for example the formulation of questions or items which must be clear; (3) Language, for example the formulation of questions does not use words/ sentences that lead to double interpretation; (4) Writing rules, must be guided by the rules of writing standard questions from various forms of assessment questions (Vrieling, Stijnen, \& Bastiaens, 2018).

The role of school principals/ supervisors/ assessors/ peers to support teachers' readiness in developing assessment tools to measure the science concept mastery through inquiry-based learning processes in elementary schools was obtained by asking questions/ statements which included: (1) Interaction between teachers and peers in the was very useful to develop your skills so that you could carry out the inquiry-based learning process well in elementary school; (2) Competency of supervisor/ assessor directly which was related to the implementation of learning in elementary school influenced your readiness to be able to carry out learning process well in elementary school; (3) The direction and guidance of the supervisor/assessor supports me to make a plan for improving learning process and assessment well in elementary school; and (4) The facilities and infrastructure available at the TWG supported me to be able to carry out learning well in elementary school. In general, elementary school teacher' responses to role of school principals/ supervisors/ assessors/ peers to support teachers' readiness in developing assessment tools to measure the science concept mastery through inquiry-based learning processes in elementary schools can be seen in Figure 5. 


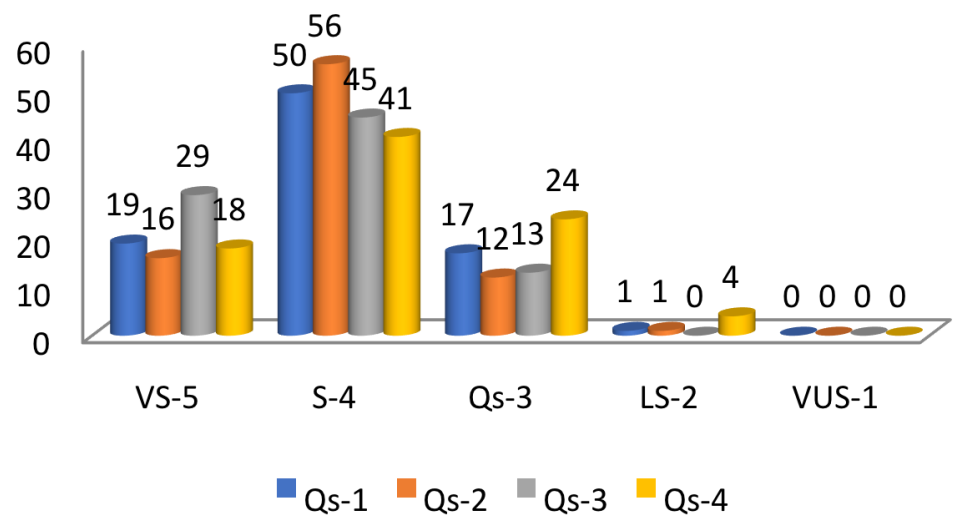

Figure 5.

Teachers' Responses toward Role of School Principals, Supervisors, Assessors, Peers to Support Teachers' Readiness in Developing Assessment Tools to Measure the Science Concept Mastery Through Inquiry-Based Learning Processes in Elementary Schools

Elementary school teachers stated that school principals, supervisors, colleagues from both the same elementary school and peers from different elementary schools has a role for them to improve their abilities even though it is not optimum yet (Ndibalema, 2019). The interaction between teachers and peers in the TWG is very useful to develop their abilities so that they can carry out assessments to measure the mastery of the concept of inquiry-based science in elementary schools (Reddy, Glover, Kurz, \& Elliott, 2019). The competency of school principals/ supervisors who are directly related to the implementation of learning in elementary school influences the readiness to be able to prepare the inquiry-based science problem well in elementary schools. Guidance from principals/ supervisors support teachers to be able to produce assessment tools to measure mastery of the concept of science-based inquiry properly in elementary schools (Wong \& Daud, 2017). The facilities and infrastructure available at the TWG can support teachers to be able to arrange inquiry-based science questions well in elementary schools (Bolinger \& Burch, 2018).

\section{CONCLUSION}

This research showed that science was an interesting subject matter to teach in elementary school. However, some teachers stated that science materials were quite difficult to teach in elementary school. Science required the students to be active in the learning process to find the concepts they were learning. Teaching inquiry-based science required teachers to take more time to prepare the lesson plan, tools and learning materials (science equipment). The factors that supported the readiness of teachers to measure the learning process of inquiry-based science in elementary schools, among others they had sufficient ability to develop lesson plans which were inquiry-oriented and peers who played an important role so that they could measure the learning process. The teachers' working group was also considered to play an important role in supporting the ability of elementary school teachers to measure the inquirybased science learning process in elementary schools. Some of the obstacles of teachers in assessing the learning process and outcomes were the lack of understanding to the importance of the ability to measure the mastery of student concepts based on the inquiry-based science learning process in elementary schools, the insufficient time allocation for inquiry-based learning processes, limited teaching aids or facilities and infrastructure. Some of the efforts that have been made by teachers to develop assessment tools to measure students' mastery of science concepts were to use questions which were fully downloaded from the lesson plan available on the internet, develop their own questions to measure the mastery of science concepts through inquiry-based learning process in elementary school, and utilize the TWG 
and school principals/ inspectors to produce assessment tools to measure mastery of the concept of inquiry-based science in elementary schools.

\section{References}

Akerson, V. L., Carter, I., Pongsanon, K., \& Nargund-Joshi, V. (2019). Teaching and learning nature of science in elementary classrooms. Science \& Education, 1-21.

Akiba, M., Murata, A., Howard, C. C., \& Wilkinson, B. (2019). Lesson study design features for supporting collaborative teacher learning. Teaching and Teacher Education, 77, 352-365.

Arnold, J., Boone, W., Kremer, K., \& Mayer, J. (2018). Assessment of competencies in scientific inquiry through the application of rasch measurement techniques. Education Sciences, 8(4), 184.

Arnold, M. M., Graham, K., \& Hollingworth-Hughes, S. (2017). What's context got to do with it? Comparative difficulty of test questions influences metacognition and corrected scores for formula-scored exams. Applied Cognitive Psychology, 31(2), 146-155.

Bolinger, A. R., \& Burch, T. C. (2018). When it comes to task assignment, sometimes you gotta “LEGO" ( delegation principles with Mega Bloks@. Management Teaching Review, 3(4), 320-330.

Boud, D., \& Soler, R. (2016). Sustainable assessment revisited. Assessment \& Evaluation in Higher Education, 41(3), 400-413.

Budiastra, A., \& Purwoningsih, T. (2014). Studi pendahuluan pengembangan model pelatihan untuk meningkatkan kemampuan guru mengajarkan IPA berbasis inkuiri di SD melalui forum TWG dalam konteks pendidikan jarak jauh [A preliminary study developed a training model to improve the ability of teachers to teach inquiry-based science in elementary school through a TWG forum in the context of distance education]. Open University Repository. 2 (3). 7-53.

Cairns, D., \& Areepattamannil, S. (2019). Exploring the relations of inquiry-based teaching to science achievement and dispositions in 54 countries. Research in Science Education, 49(1), 1-23.

Chevalier, J. M., \& Buckles, D. J. (2019). Participatory action research: Theory and methods for engaged inquiry: Routledge.

Deieso, D., \& Fraser, B. J. (2019). Learning environment, attitudes and anxiety across the transition from primary to secondary school mathematics. Learning Environments Research, 22(1), 133-152.

Demetriou, A., Makris, N., Spanoudis, G., Kazi, S., Shayer, M., \& Kazali, E. (2018). Mapping the dimensions of general intelligence: An integrated differential-developmental theory. Human Development, 61(1), 4-42.

Demir, M., Tananis, C. A., \& Trahan, K. W. (2019). Evaluation of alternative assessment methods used in elementary schools. Egitim ve Bilim, 44(197).

Fry, J., Klages, C., \& Venneman, S. (2018). Using a written journal technique to enhance inquiry-based reflection about teaching. Reading Improvement, 55(1), 39-48.

Fuller, S. (2019). Philosophy of science and its discontents New York: Routledge.

García-Carmona, A. (2019). Pre-service primary science teachers' abilities for solving a measurement problem through inquiry. International Journal of Science and Mathematics Education, 17(1), 1-21.

Handayani, F., Hartono, H., \& Lestari, W. (2019). Need analysis in the development of HOTS-oriented study project assesment instrument in android-based science learning. Journal of Educational Research and Evaluation, 8(1), 5764.

Hondrich, A. L., Hertel, S., Adl-Amini, K., \& Klieme, E. (2016). Implementing curriculum-embedded formative assessment in primary school science classrooms. Assessment in Education: Principles, Policy \& Practice, 23(3), 353-376.

Inoue, N., Asada, T., Maeda, N., \& Nakamura, S. (2019). Deconstructing teacher expertise for inquiry-based teaching: Looking into consensus building pedagogy in Japanese classrooms. Teaching and Teacher Education, 77, 366-377.

Istianto, D. A. (2012). Penggunaan metode inkuiri dalam peningkatan hasil belajar matematika di kelas v sekolah dasar [The use of inquiry methods in improving mathematics learning outcomes in grade v primary schools]. Kalam Cendekia PGSD Kebumen, 1(1). 
Budiastra, A. K., Erlina, N., \& Wicaksono, I. (2019). The Factors Affecting Teachers' Readiness In Developing Science Concept Assessment Through Inquiry-Based Learning Process In Elementary Schools. Advances in Social Sciences Research Journal, 6(9) 355-366.

Kuo, Y.-R., Tuan, H.-L., \& Chin, C.-C. (2019). Examining low and non-low achievers' motivation towards science learning under inquiry-based instruction. International Journal of Science and Mathematics Education, 17(5), 845862 .

Laursen, S. L., \& Rasmussen, C. (2019). I on the prize: Inquiry approaches in undergraduate mathematics. International Journal of Research in Undergraduate Mathematics Education, 5(1), 129-146.

Le Hebel, F., Tiberghien, A., Montpied, P., \& Fontanieu, V. (2019). Teacher prediction of student difficulties while solving a science inquiry task: example of PISA science items. International Journal of Science Education, 1-24.

Lee, D. A., Baker, W., \& Haywood, N. (2018). Instrumental teacher education and the incoming tide of information technology: A contemporary guitar perspective. Australian Journal of Teacher Education, 43(5), 17-31.

Liu, S., \& Hallinger, P. (2018a). Principal instructional leadership, teacher self-efficacy, and teacher professional learning in China: testing a mediated-effects model. Educational Administration Quarterly, 54(4), 501-528.

Liu, S., \& Hallinger, P. (2018b). Teacher development in rural China: how ineffective school leadership fails to make a difference. International Journal of Leadership in Education, 21(6), 633-650.

Ndibalema, P. (2019). Professional integrity among pre-service teachers during teaching practice: experience from school leaders in Misungwi District, Tanzania. Teacher Education and Curriculum Studies, 4(1), 9.

Öberg, G., \& Campbell, A. (2019). Navigating the divide between scientific practice and science studies to support undergraduate teaching of epistemic knowledge. International Journal of Science Education, 41(2), 230-247.

Owiny, R. L., Hollingshead, A., Barrio, B., \& Stoneman, K. (2019). Engaging preservice teachers in universal design for learning lesson planning. Inclusion, 7(1), 12-23.

Popescu, C. (2019). The assesment process of various types of education in terms of the roles involved in the teaching and learning processes. Case study. Analele Universităţii Ovidius din Constanţa. Seria Filologie, $30(1), 137$ 145.

Reddy, L. A., Glover, T., Kurz, A., \& Elliott, S. N. (2019). Assessing the effectiveness and interactions of instructional coaches: Initial psychometric evidence for the Instructional Coaching Assessments-Teacher Forms. Assessment for Effective Intervention, 44(2), 104-119.

Sayko, N. (2018). Conceptual approaces to proffesional training of future social pedagogues for social rehabilitation of pupils at schools. Social work and education, 5(1), 67-78.

Semken, S., \& Freeman, C. B. (2008). Sense of place in the practice and assessment of place-based science teaching. Science Education, 92(6), 1042-1057.

Sherfinski, M., Jalalifard, M., Zhang, J., \& Hayes, S. (2019). Narrative portfolios as culturally responsive resistance to neoliberal early childhood teacher education: A case study. Journal of Research in Childhood Education, 33(3), 490519.

Şimşir, Z., Seki, T., \& Dilmaç, B. (2018). Predictive relationship between adolescents' spritual well-being and perceived social support: The role of values. Research on Education and Psychology, 2(1), 37-46.

Tan, F. D., Whipp, P. R., Gagné, M., \& Van Quaquebeke, N. (2019). Students' perception of teachers' two-way feedback interactions that impact learning. Social Psychology of Education, 22(1), 169-187.

Tican, C., \& Deniz, S. (2019). Pre-service teachers' opinions about the use of 21st century learner and 21st century teacher skills. European Journal of Educational Research, 8(1), 181-197.

Uçar, F. M., \& Sungur, S. (2017). The role of perceived classroom goal structures, self-efficacy, and engagement in student science achievement. Research in Science \& Technological Education, 35(2), 149-168.

Vorholzer, A., \& von Aufschnaiter, C. (2019). Guidance in inquiry-based instruction-an attempt to disentangle a manifold construct. International Journal of Science Education, 1-16.

Vrieling, E., Stijnen, S., \& Bastiaens, T. (2018). Successful learning: balancing self-regulation with instructional planning. Teaching in Higher Education, 23(6), 685-700.

White, M., Randall, K., Capo-Chichi, N., Sodogas, F., Quenum, S., Wright, K., . . Leather, A. (2019). Implementation and evaluation of nationwide scale-up of the Surgical Safety Checklist. British Journal of Surgery, 106(2), e91-e102.

Wong, A. Y., \& Daud, K. (2017). Headmaster technology leadership in Malaysia Elementary Schools. Journal of Education and Learning, 11(2), 154-164 